\title{
Occurrence of Manganese Ore Deposits and Their Mineralogy in Vizianagaram-Visakhapatnam Manganese Ores Belt (Andhra Pradesh) India
}

\author{
Farhat Nasim Siddiquie, Juned Alam, Mohd Shaif \\ Department of Geology, Aligarh Muslim University, Aligarh, India \\ Email: fnaseem2000@yahoo.com
}

Received 8 May 2015; accepted 13 June 2015; published 16 June 2015

Copyright (C) 2015 by authors and Scientific Research Publishing Inc.

This work is licensed under the Creative Commons Attribution International License (CC BY). http://creativecommons.org/licenses/by/4.0/

\section{(c) (i) Open Access}

\section{Abstract}

The Manganese deposits of Andhra Pradesh are associated with a thick sequence of Precambrian rocks, belonging to Khondalite and Charnockite groups of Dharwar Supergroup that forms part of 2500 to 3000 m.y. old Eastern Ghat complex of India. The study area is the Manganese deposits of Vizianagram-Visakhapatnam Manganese Belt of Andhra Pradesh. The study area lies about 150 $\mathrm{km}$ NE of Visakhapatnam between $18^{\circ} 12^{\prime} \mathrm{N}-18^{\circ} 30^{\prime} \mathrm{N}$ and $83^{\circ} 20^{\prime} \mathrm{E}-8^{\circ} 45^{\prime} \mathrm{E}$. The mineralization of Manganese ores is confined to different rock types, belonging to both Khondalite and Charnockite groups, where they are dispersed throughout the country rocks as small lenses, pockets, veins and irregular bodies of varying dimensions. Quartz, garnet, clay, limonite and apatite are the common gangue minerals in the Manganese ores. The presence of quartz, garnet and apatite brings down the grade of the ore. Ferruginous laterite and ochre generally work as capping of the Manganese deposits. The various Manganese ore minerals present in these deposits are indentified as 1) Primary minerals-braunite, bixbyite, vredenburgite, jacobsite and hausmannite, 2) secondary minerals-psilomelane, cryptomelane, hollandite, pyrolusite and wad. The primary ore minerals are considered to be syngenetic and regionally metamorphosed while, the associated secondary ore minerals are formed due to alteration of the primary ores.

\section{Keywords}

Manganese Ore, Vizianagram, Andhra Pradesh, Dharwar Supergroup, Primary and Secondary Ores, Oxidation Zone, Ore Body, Open Cast Mine/Quarry 


\section{Introduction}

The present study reveals a systematic mineragraphic and paragenetic study of the manganese ores. The samples of manganese ores have been collected from the different benches of the quarries where the area is under active exploitation by open cast methods. Most of the ore is extracted from the oxidation zone. The ore body mainly occurs in association of para-gneisses of the Archaean age. The primary ore body consisting of silicates and oxides lies at a depth of $350 \mathrm{~m}$ and is intercalated with other para-gneisses [1].

Manganese ores are widely distributed throughout the Peninsular India (Figure 1). Stratigraphically, these are

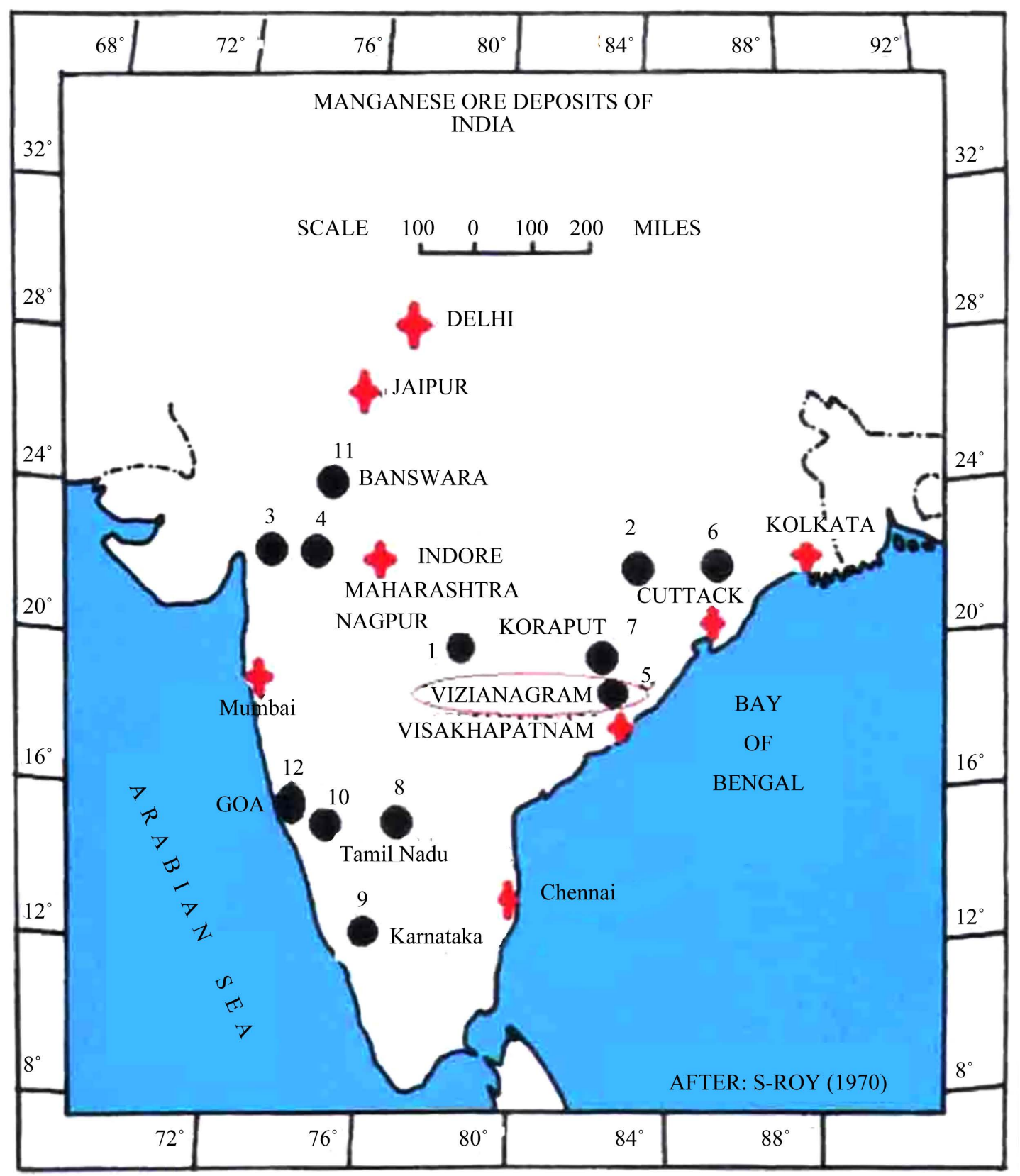

Figure 1. Map showing manganese ore deposits in India. 1. Madhya Pradesh-Maharashtra ore belt. 2. GangpurBamra deposits. 3. Panch Mahals district Deposits. 4. Jhabua district Deposits, Madhya Pradesh. 5. Vizianagram district deposits, Andhra Pradesh. 6. Bonai-Keonjhar deposits, Orissa. 7. Kalahandi-Koraput-Patna deposits, Orissa. 8. Sandur-Bellary deposits, Mysore. 9. Shimoga district deposits, Mysore. 10. North-Kanara deposits, Mysore. 11. Banswara deposits, Rajasthan. 12. Goa deposits. 
mainly confined to the Precambrian terrain and are encountered in the Sausar Group and Aravalli Supergroup of central and western India, Iron ore Group and Gangpur Group of eastern India. In Andhra Pradesh there are major occurrences of Manganese ores in Vizianagram-Visakhapatnam Manganese Belt. The deposit occurs in this belt over an area of $50 \mathrm{kms}$. in length and $20 \mathrm{kms}$. in width. The study areas include Garividi, Garbham and Chipurupalle areas and are located at $150 \mathrm{kms}$ NE of Visakhapatnam (Figure 2).

\section{Geology of the Study Area}

The host rocks of Manganese ore in Vizianagram-Visakhapatnam Manganese Belt are khondalites and charnockites belonging to Dharwar Supergroup of Precambrian age [2] which forms a part of the Eastern Ghat complex of India (Figure 3). The Kodurite Series of rocks in which Manganese ores occur also crop out at several places in this belt [3].

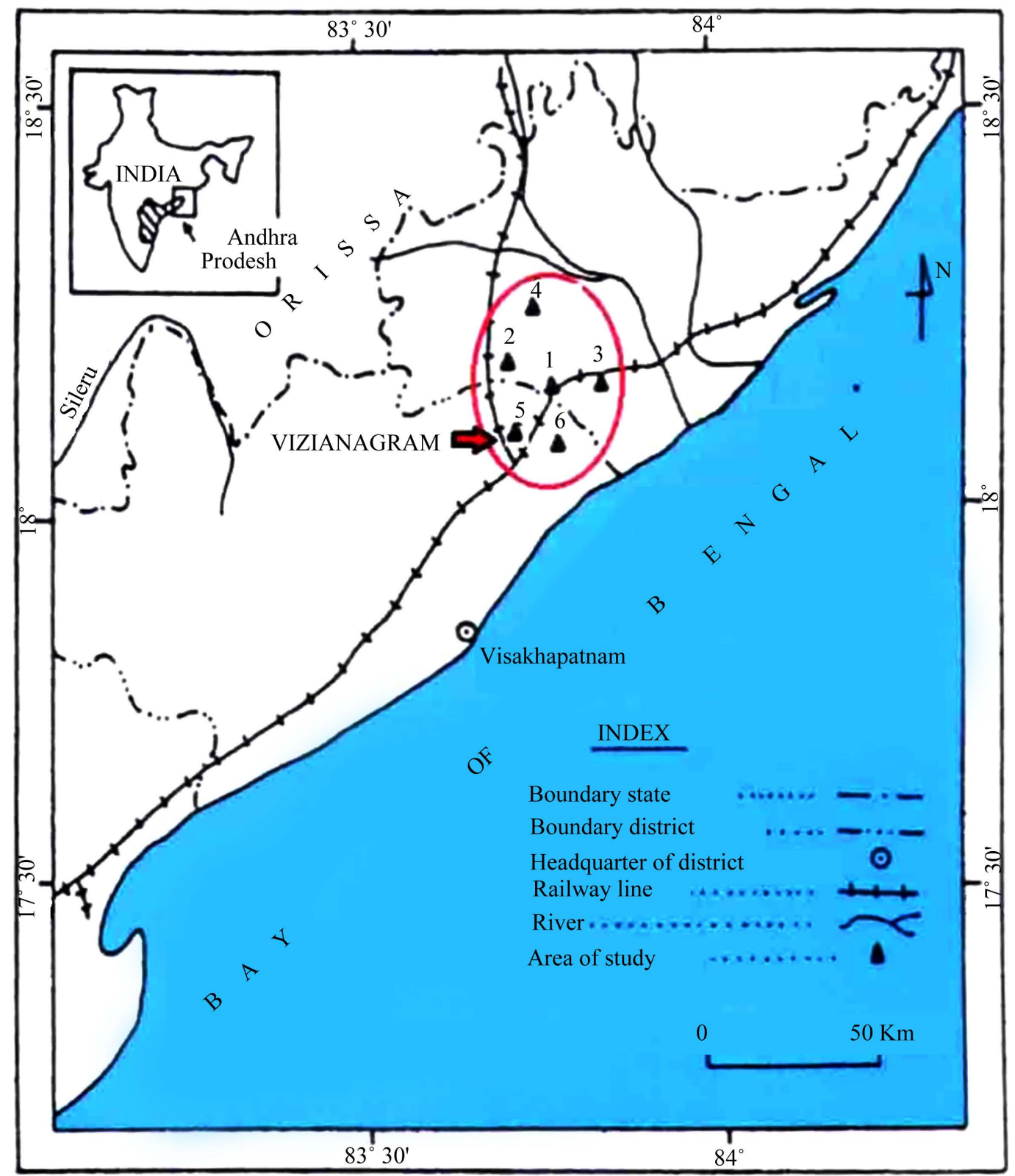

Figure 2. Location map of garividi, garbham and chipurupalle manganese deposits, Vizianagram-Visakhapatnam Manganese Belt (A.P.). 


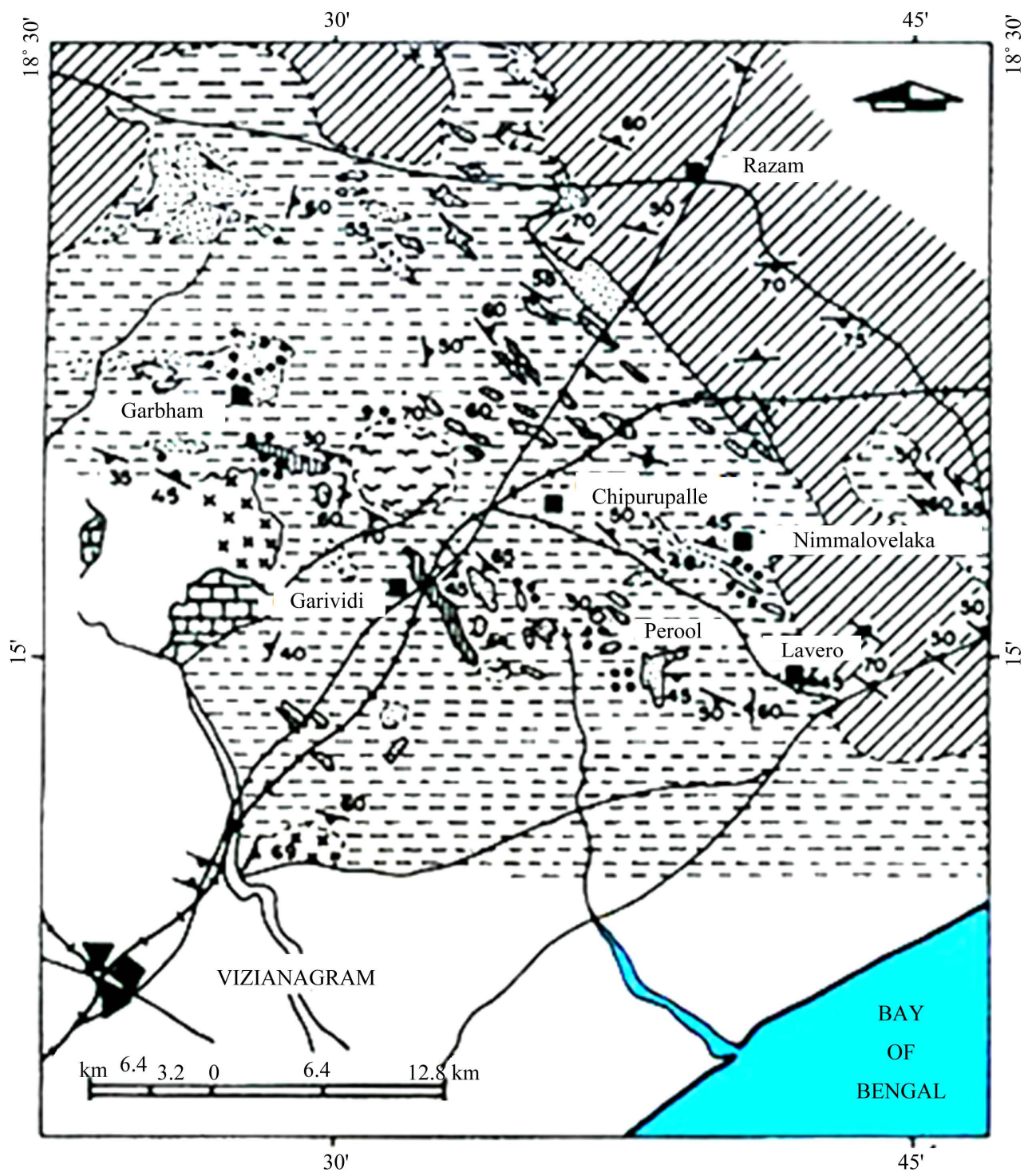

After: F.N. Siddiquie (2000)

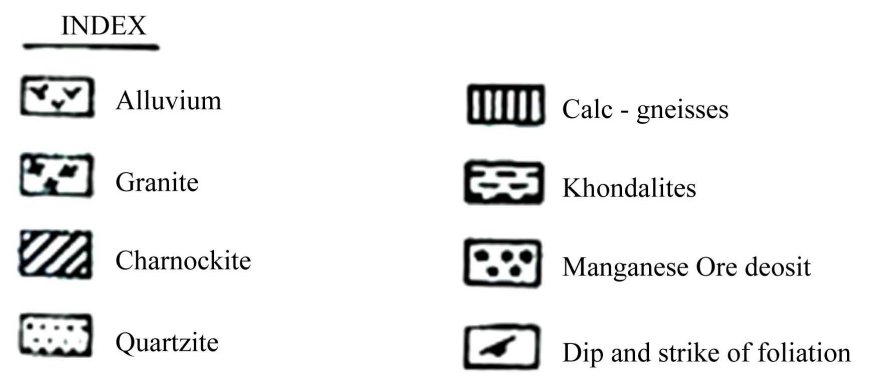

Figure 3. A generalised geological map of garividi, garbham and chipurupalle manganese deposits, vizianagaram district. (A.P.).

The ores are associated primarily with calc-granulite, often with quartzite and quartz + garnet + sillimanite + graphite gneiss belonging to granulite facies [4]-[6]. The Mn-bearing rocks are generally disposed in NW-SE direction [5]. 
Geological succession of the area as proposed by [2] and [7] and modified by [8]-[12] is given as follows.

Geological succession of Garividi, Vizianagram, (A.P). [10]

\begin{tabular}{|c|c|c|}
\hline Age & Group & Rock types \\
\hline Recent & & Aluvium and Soil \\
\hline Pleistocene (?) & & Laterite-limonite and ochre \\
\hline Miocene (?) & & Sandstone \\
\hline & & Pegmatite and quartz Veins \\
\hline & & Granite and granite Gneisses \\
\hline & & Hypersthene Gneisses (porphyro-blastic) \\
\hline & Charnockite & (charnockite) granulitic hypersthene diorite and \\
\hline & & granite gneisses (charnockite) \\
\hline \multirow{10}{*}{ Archaeans } & & Garnet sillimanite gneisses (Khondalite) \\
\hline & & $\begin{array}{l}\text { Garnet Granulites—MANGANESE ORE } \\
\text { (HORIZON-I) }\end{array}$ \\
\hline & & *Crystalline algal limestone Archaeans \\
\hline & & *Green shale pockets, Clac-granulite + lenses of red shale \\
\hline & $\begin{array}{l}\text { Khondalite } \\
\text { Group }\end{array}$ & $\begin{array}{l}\text { Garnet granulites-MANGANESE ORE } \\
\text { (HORIZON-II) }\end{array}$ \\
\hline & & Coarse grained quartzite \\
\hline & & $\begin{array}{l}\text { Feldspathic quartzite with lenticular bands of garnetifeous } \\
\text { quartzite -MANGANESE ORE }\end{array}$ \\
\hline & & (HORIZON-III) \\
\hline & & Coarse grained quartzite \\
\hline & & $\begin{array}{l}\text { Garnet-sillimanite-gneisses } \\
\text { (Khondalite) }\end{array}$ \\
\hline & & Biotite Gneisses \\
\hline
\end{tabular}

*Two horizons were not reported by earlier workers, reported for the first time by the present author [10].

Bulk of the ore is composed of secondary cryptomelane-psilomelane and pyrolusite which are of commercial grade. Main ore bodies usually occur as lodes which are sometimes bifurcating. The shape of the lode is generally lenticular, there are some irregular pockets also. Quartz, garnet, clay, limonite and apatite are the common gangue minerals in these Manganese ores. The primary ores are considered to be syngenetic and regionally metamorphosed [13]. The associated secondary ores owe their origin to subsequent alteration of the primary ores followed by secondary enrichment.

\section{General Statement of Main Mines}

\subsection{Garividi Mines}

Garividi mine is named after the Garividi village, situated at $18^{\circ} 17^{\prime} \mathrm{N}$ latitude and $83^{\circ} 32^{\prime} \mathrm{E}$ longitude. The manganese quarries are situated about $800 \mathrm{~m}$ WNW of Garividi village. The main quarry is about $245 \mathrm{~m} \times 92 \mathrm{~m}$ with a maximum depth of about $9 \mathrm{~m}$. The Garividi block is further sub-divided into five main groups, viz., Garividi, Koduru, Duvvam, New Devada and Sadanandapuram.

\subsection{Garbham Mines}

It is also named after the village Garbham, situated at $18^{\circ} 17^{\prime} \mathrm{N}$ latitude and $83^{\circ} 32^{\prime} \mathrm{E}$ longitude. The manganese ores were first reported and mined in the country from this area. The quarries are spread over an area of about 80 sq. $\mathrm{km}$. The main quarry is abandoned and water-logged, but it is the oldest and the deepest manganese quarry in India. The ore can be traceable over a strike length of $660 \mathrm{~m}$ due east coast and extended westward. 
There are two manganese belts, Kottakarra-Garbham belt in the north and Gadassam-Chinnabantupalle belt in the south.

\subsection{Chipurupalle Mines}

This is named after the railway station Chipurupalle and situated at $18^{\circ} 18^{\prime} \mathrm{N}$ latitude and $83^{\circ} 35^{\prime} \mathrm{E}$ longitude. The area shows a large number of big and small deposits of manganese and most of the quarries are abandoned. Only two quarries that are in working state cover an area of about $225 \mathrm{sq}$. km. The trend of formation is NW to SE. The Chipurupalle block is divided into six quarries, viz., Batuva, Avagudem, Karlam, Govendapuram, Pandanadepalle and Palavalsa.

\section{Mode of Occurrence}

By and large the manganese ores occur associated mainly with calc-granulite and granite-gneiss, namely at Koduru, Kondapalam and Sadanandapuram. The Koduru manganese ore have small pockets of crystalline algal limestone at Garividi near vibhu soda Factory with the association of green shale. The manganese ores in Dhobi pit occur in association with the red shale lenses.

At Garbham, ore body is found in association with quartzite (feldspathic and garnetiferous) particularly in the East Garbham group of quarries. The Garbham main quarry at Srinivasa shows weathered calc-granulite, Quartzofeldspathic rocks, underlying the quartzite. A few working quarries in the Central Garbham show that the ore occurs associated with lateritic material. The lateritic materials also contain fragments of quartz and red loamy material which is rich in the iron oxides.

\section{QUARTZITE ASSOCIATION}

1. Strata bound, cofolded with well defined contact.

2. Hard and lumpy in general

3. Generally of low grade, 18 - 28 percent.

4. Consists of manganese sillicate and garnet with small band of steel gray and fine-grained material.

5. The width and thickness of ore zone is generally smaller.

6. There are a few pockets of garnet-granulite, lithomarge, chert and limonite.

\section{CALC-GRANULITE ASSOCIATION}

1. Strata bound, cofolded with Diffused contacts.

2. Mostly powdery with occasional lumpy ore.

3. Higher in Mn content. Generally 30 - 32 percent Mn with pockets of high grade material

4. Consists of mostly pyrolusite psilomelane, braunite and jacobsite with small amounts of garnet and manganese sillicate.

5. The width and thickness of ore zone is greater.

6. Intimately associated with Pockets and bands of lithomarge, chert and limonite.

7. Coarse quartzofeldspathic rock is invariably present at the foot-wall side and between the underlying rock and manganese ore.

In the East Garbham group of quarries, the ores also have association of garnet and gneiss and calc-granulite.

In Chipurupalle the manganese ores occur associated with quartzite, weathered calc-granulite and laterite (perfectly in the form of honeycomb). The shape of laterite is due to the chemical weathering.

However, the geological association in all the three areas is not clear owing to the highly weathered nature of rocks. The highly weathered formation consists of high proportion of feldspar (completely or partly kaolinised) and quartz. These rocks exhibit relict banding and occasional presence of calc-granulite boulders.

The size of the working quarries more or less reflect the size of exposed ore bodies. The largest ore bodies encountered in the Saibaba and Sadanandapuram (main pit) are $200 \mathrm{~m} \times 80 \mathrm{~m} \times 29 \mathrm{~m}$ and $100 \mathrm{~m} \times 80 \mathrm{~m} \times 20 \mathrm{~m}$ respectively. The information available from bore hole data in the Koduru quarry, the bands of manganese ore are interbedded with clay and chert, persist up to depth of $67.97 \mathrm{~m}$.

The main ore body occurs in the form of lode and often bifurcated (Figure 4). Sometimes it is lenticular in shape and occurs in pockets. Occasionally the ores occur as intercalations in the calc-granulites, whereas the main ore bodies alternate with the host rock as distinct bands.

Various types of folds and faults are also recorded in the ore bodies such as an anticline plunge in the ore body at border of main pit and road site pit at Sadanandapuram (Figure 4). Radial type of faults could be seen at the contact of ore body and calc-granulite in Dhobi pit (Figure 5). 


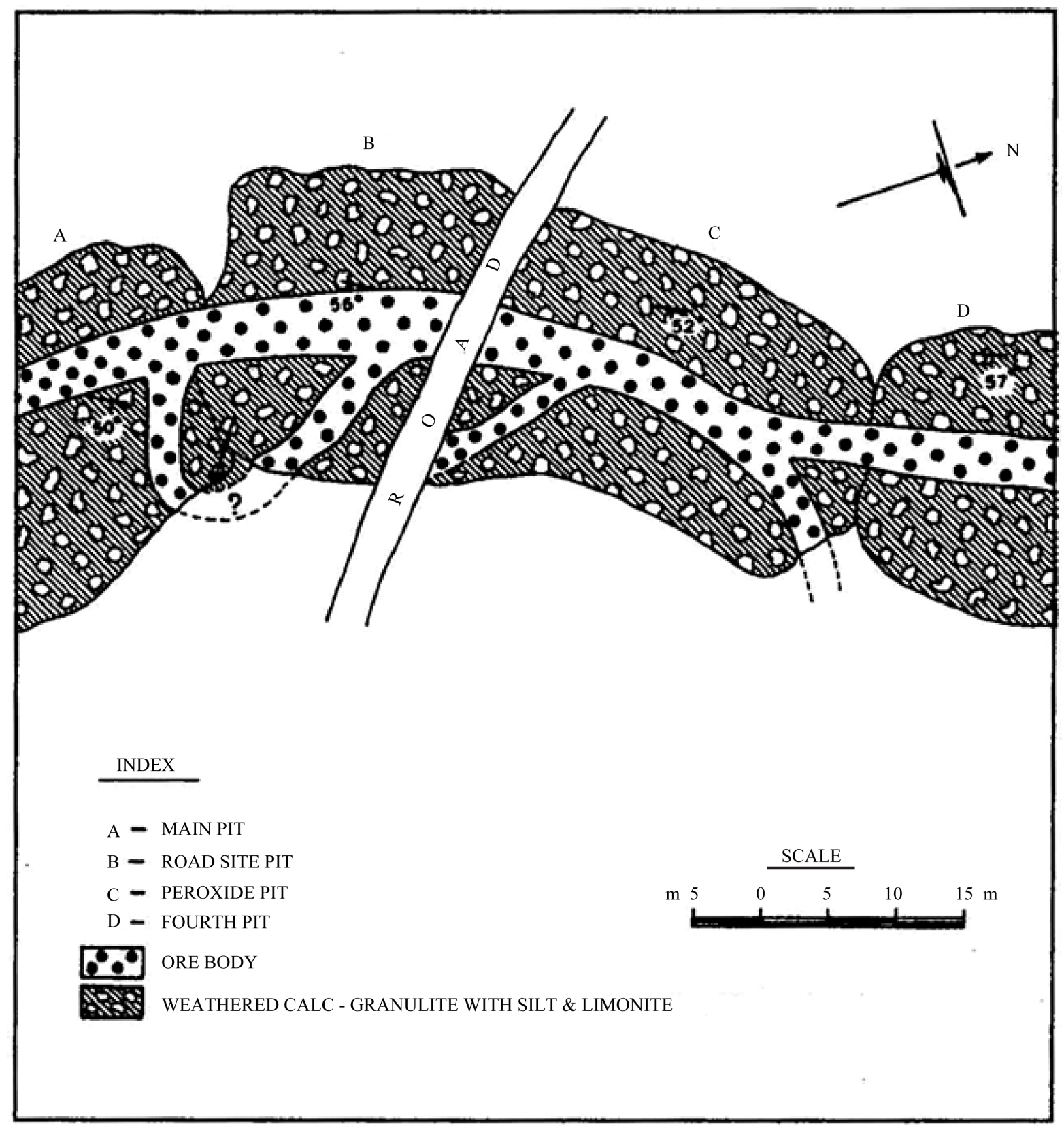

Figure 4. Sketch Depicting the main structure of the Ore Body at Sadanandapuram, Garividi, Vizianagram-Visakhapatnam Manganese Belt (A.P.).

\section{Mineralogy}

The manganese ores, collected from different mines are megascopically examined and found to be largely composed of pyrolusite, psilomelane-cryptomelane and wad. A small amount of jacobsite also occurs associated with the ore. There are also some iron ores like ferruginous laterite and ochres (Table 1) show the capping of manganese deposits. The physical properties of the various ore minerals, collected from the study area are described as follows:

\subsection{Pyrolusite $\left(\mathrm{MnO}_{2}\right)$ (Figures 6-9)}

Pyrolusite occurs in the form of finely crystalline to non-crystalline varieties of manganese dioxide. It is commonly 


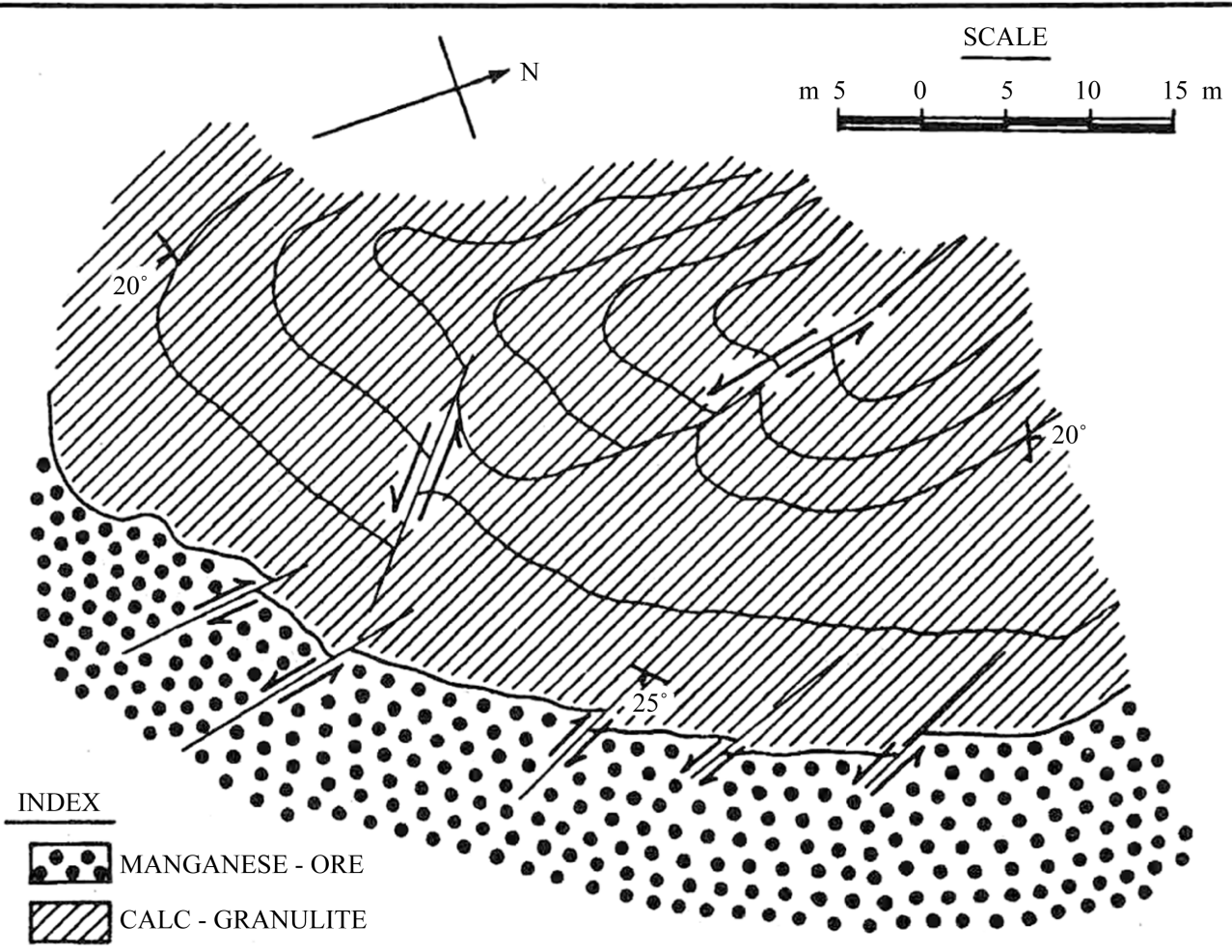

Figure 5. Sketch of a Radial Type of Faulting in the contact between Manganese Ore and Calc-Granulite at Dhobi Pit, Garividi, Vizianagram-Visakhapatnam Manganese Belt (A.P.).

Table 1. Mineralogy of the manganese ores of Vizianagram-Visakhapatnam Manganese Belt (A.P.) India.

\begin{tabular}{|c|c|c|c|c|c|}
\hline \multicolumn{6}{|c|}{ MINERALOGY } \\
\hline Mines & $\begin{array}{c}\text { Silicate } \\
\text { (Metamorphic } \\
\text { phase) }\end{array}$ & $\begin{array}{c}\text { Carbonate } \\
\text { (Metamorphic } \\
\text { phase) }\end{array}$ & $\begin{array}{c}\text { Oxides } \\
\text { (Metamorphic } \\
\text { phase) }\end{array}$ & $\begin{array}{c}\text { Oxides } \\
\text { (Colloidal and } \\
\text { supergene phase) }\end{array}$ & $\begin{array}{c}\text { Associated minerals } \\
\text { (Gangue) }\end{array}$ \\
\hline \multicolumn{6}{|c|}{ 1. Associated with quartzite } \\
\hline \multirow[t]{2}{*}{ GARIVIDI } & $\begin{array}{l}\text { Braunite Manganese } \\
\text { Diopside \& Calcite }\end{array}$ & - & $\begin{array}{l}\text { Braunite Jacobsite } \\
\text { Vredenburgite }\end{array}$ & $\begin{array}{l}\text { Pyrolusite Psilomelane } \\
\text { Cryptomelane }\end{array}$ & $\begin{array}{l}\text { Garnet, quartz, chert, } \\
\text { kaoline, apatite }\end{array}$ \\
\hline & $\begin{array}{l}\text { Braunite Knebelite } \\
\text { (Rao et al., 1981) }\end{array}$ & - & - & $\begin{array}{l}\text { Pyrolusite Psilomelane } \\
\text { Cryptomelane }\end{array}$ & $\begin{array}{c}\text { Chert, apatite, k-feldspar, } \\
\text { kaoline, laterite, wollastonite }\end{array}$ \\
\hline GARBHAM & $\begin{array}{l}\text { Manganon Calcite } \\
\text { Manganon diopside }\end{array}$ & & & & \\
\hline CHIPURUPALLE & $\begin{array}{c}\text {-do- } \\
\text { Rhodonite }\end{array}$ & - & Braunite & -do- & $\begin{array}{c}\text { Garnet, chert, kaoline, } \\
\text { apatite, laterite, } \\
\text { k-feldspar }\end{array}$ \\
\hline \multicolumn{6}{|c|}{ 2. Associated with calc-granulite } \\
\hline GARIVIDI & Braunite & - & $\begin{array}{c}\text { Braunite } \\
\text { Jacobsite } \\
\text { Hausmannite } \\
\text { Vredenburgite } \\
\text { Bixbyite }\end{array}$ & $\begin{array}{c}\text { Pyrolusite } \\
\text { Psilomelane } \\
\text { Cryptomelane }\end{array}$ & $\begin{array}{l}\text { Garnet, kaoline, chert, } \\
\text { quartz, apatite, laterite }\end{array}$ \\
\hline GARBHAM & $\begin{array}{l}\text { Braunite spessartite-rich } \\
\text { garnet }\end{array}$ & $\begin{array}{c}\text { Rhodochrosite } \\
{[6]}\end{array}$ & -do- & -do- & -do- \\
\hline CHIPURUPALLE & Braunite & -do- & -do- & -do- & -do- \\
\hline
\end{tabular}




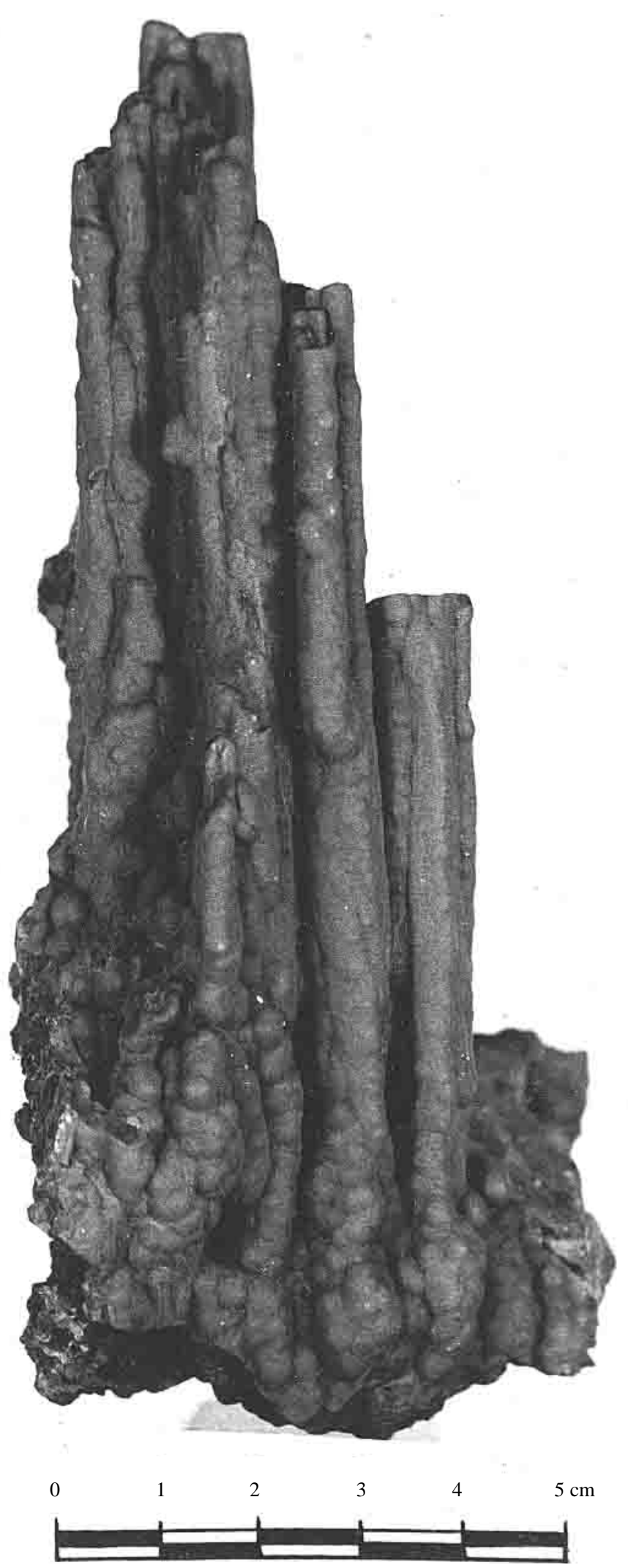

Figure 6. Stalactitic form of pyrolusite manganese ore, from pallapgudi quarry Garbham Vizianagram-Visakhapatnam Manganese Belt (A.P.). 


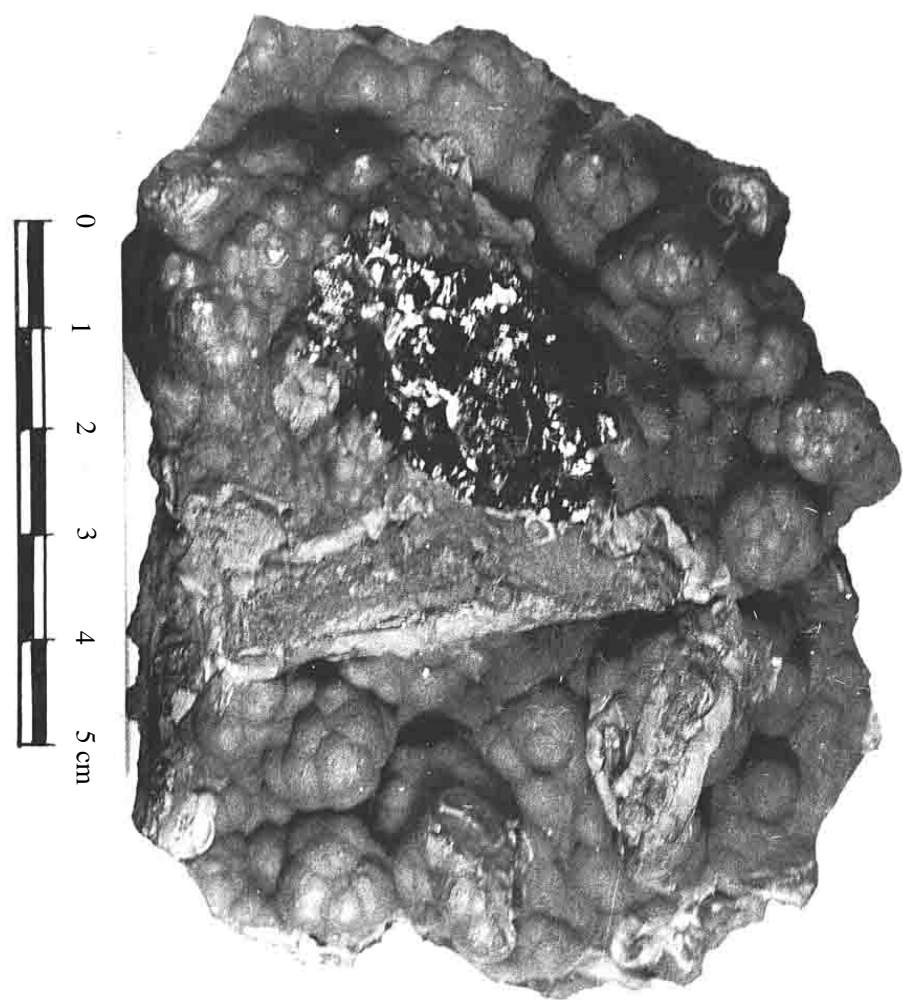

Figure 7. Mammilated form of pyrolusite manganese ore from "inclined quarry”, Garividi, Vizianagram-Visakhapatnam Manganese Belt (A.P.).

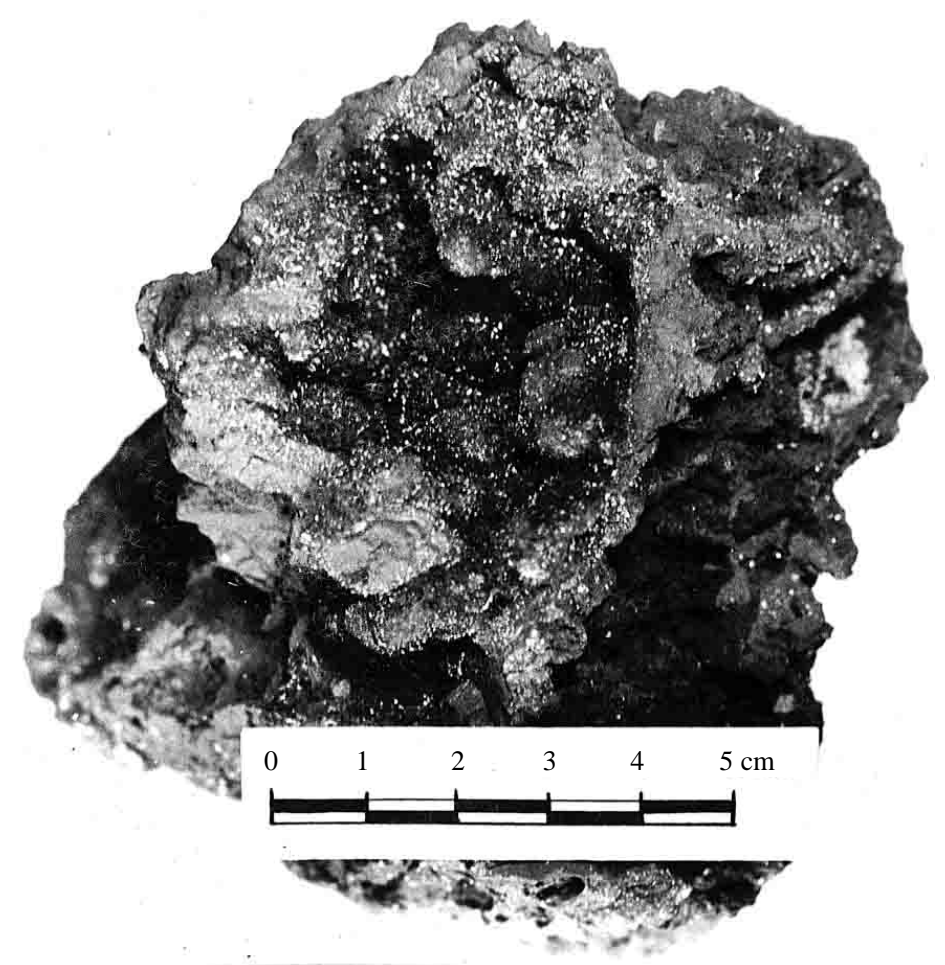

Figure 8. Pyrolusite manganese ore showing "boxwork" and pisolitic form shining crystals within cavity are also of pyrolusite pallapgudi quarry, Garbham, Vizianagram-Visakhapatnam Manganese Belt (A.P.). 


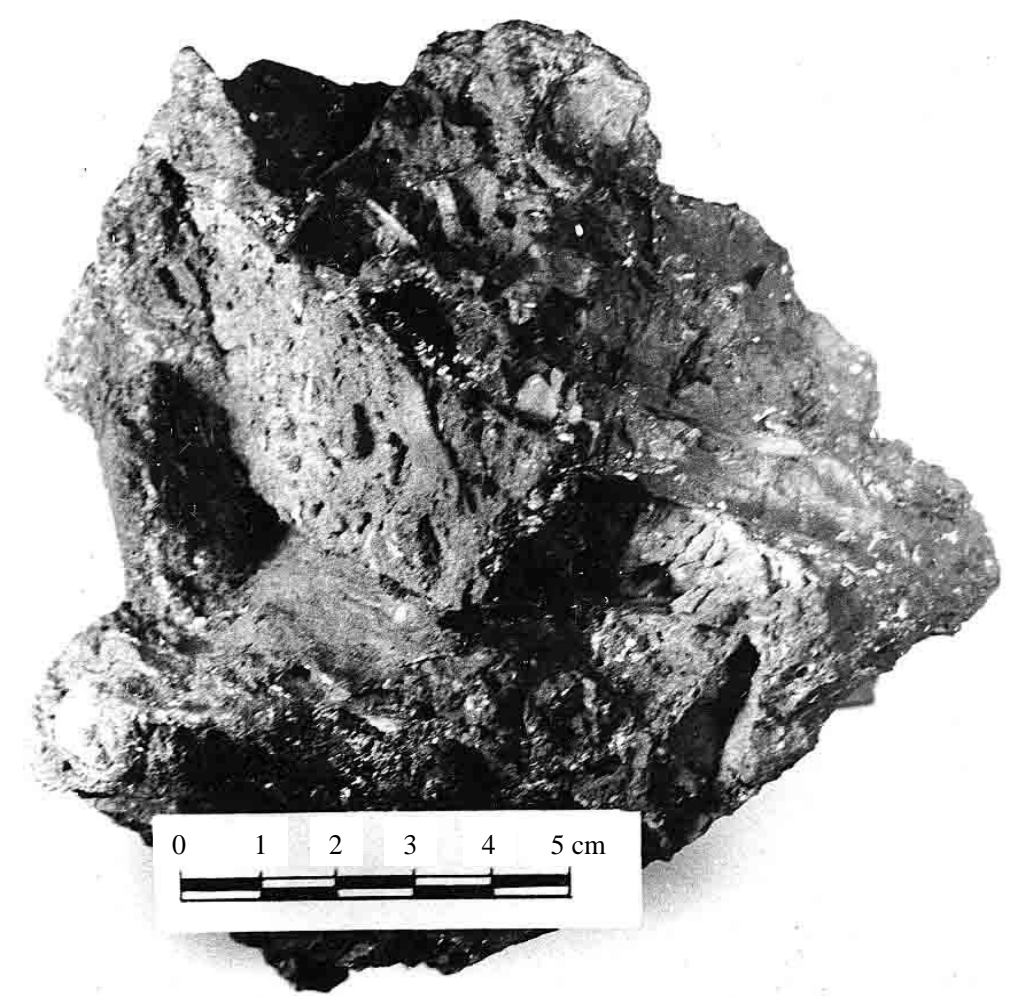

Figure 9. Box-work structure of pyrolusite manganese ore from Avagudem quarry Chipurupalle, Vizianagram-Visakhapatnam Manganese Belt (A.P.).

associated with all the varieties of the manganese ores to a greater or lesser amount. It usually occurs in dusty, columnar or fibrous form. Colour is soily black or dark steel gray; streak is dark black; hardness is 2.0 - 2.5; specific gravity is 4.7 and lusture is submetallic to metallic. The massive variety has hardness of about 2.5 . The fibrous and friable (Figure 10) varieties often soil the figures. The massive variety of pyrolusite occurs in such forms as botryoidal, mammilated, lenticular, boxwork and stalactite etc. It also occurs as a vein mineral in some earlier formed minerals.

\subsection{Psilomelane-Cryptomelane (Figure 10 and Figure 11)}

The Mn ore frequently occurs at Garbham, particularly in Sai Baba quarry (Figure 12) around a chert vein and in Garividi at Pallapgudy, Jai Bhavani, Udikimeta hill, Koruru and in the "Inclined quarry" (Figure 13) Psilomelane-Cryptomelane ores occur as botryoidal, kidney shaped, stalactitic, pisolitic and also time in nodular forms all of which are the characteristic of colloform ores. These colloform ores are frequently composed of alternating and concentric envelopes of psilomelane-cryptomelane, pyrolusite and gangue.

It is difficult to distinguish between the two minerals by their physical properties.

However, they differ in their chemical composition (Table 2) and X-ray diffraction pattern the formulae of these two minerals suggested by [14] are as follows:

Psilomelane: $\mathrm{BaR}_{9} \mathrm{O}_{18}, 2 \mathrm{H}_{2} \mathrm{O}$, RMn II-Mn IV

Cryptomelane: $\mathrm{KR}_{8} \mathrm{O}_{16}$, RMn II-Mn IV

They are iron-black in colour passing into dark steel grey, while the streak is shining brownish black on rubbing with considerable pressure. Hardness: 6.0 - 6.5 specific gravity: 4.7; fracture: sub-conchoidal.

\subsection{Wad}

Colour: brownish to steel grey with a dull appearance form; cauliflower-like (Figure 14); hardness: 2.0 - 2.5; specific gravity: 2.9 in Jai Bhavani quarry, it occurs in association with the cryptomelane-psilomelane ore. It is a very low grade manganese oxide which is characterised by its softness and low specific gravity. [20] had first 


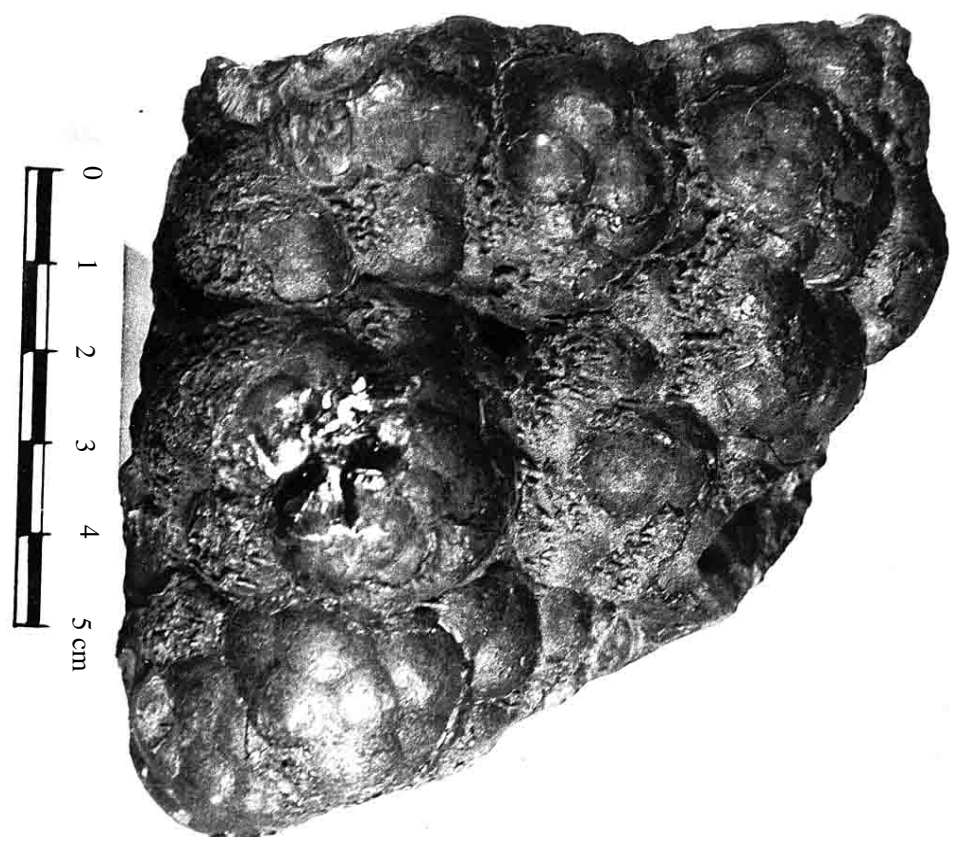

Figure 10. A hand specimen of psilomelane showing typical botryoidal or kidney-like form from Jai Bhawani quarry, Garbham, Vizianagram-Visakhapatnam Manganese Belt (A.P.).

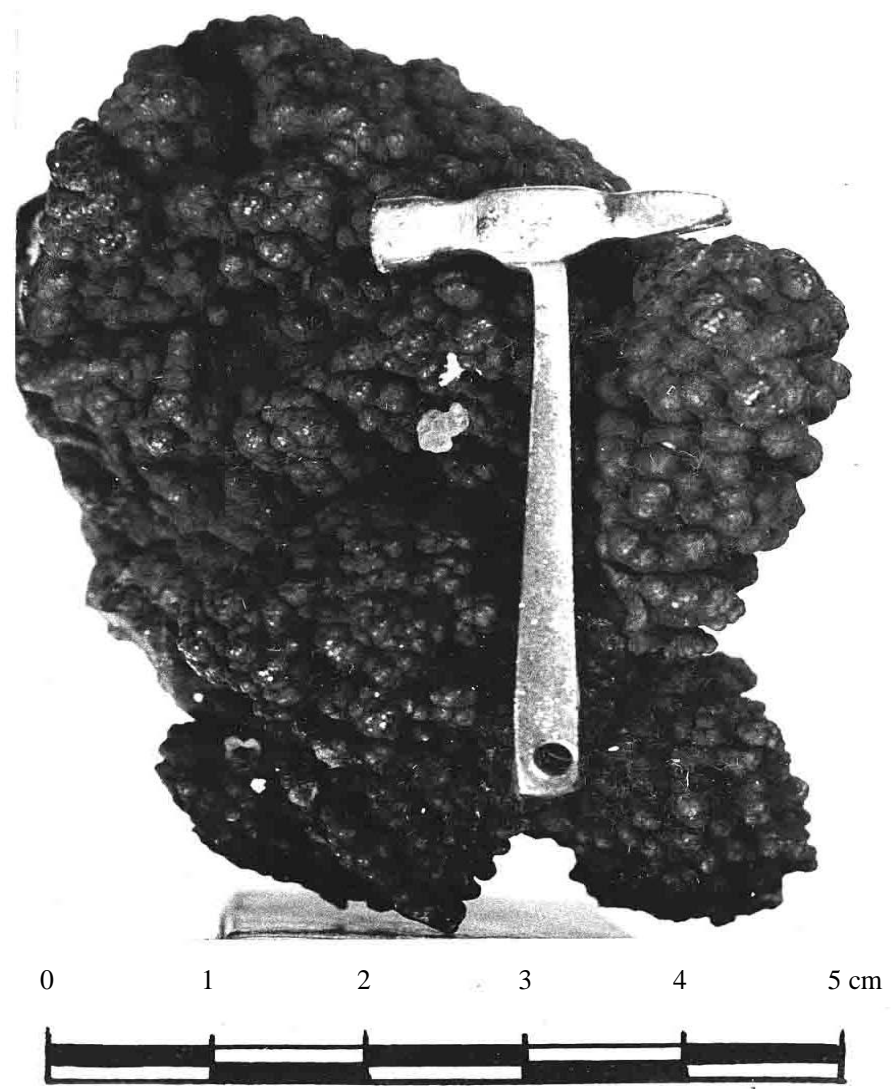

Figure 11. A hand specimen of psilomelane showing pisolitic form, pallapgudi quarry, Garbham Vizianagram-Visakhapatnam Manganese Belt (A.P.). 


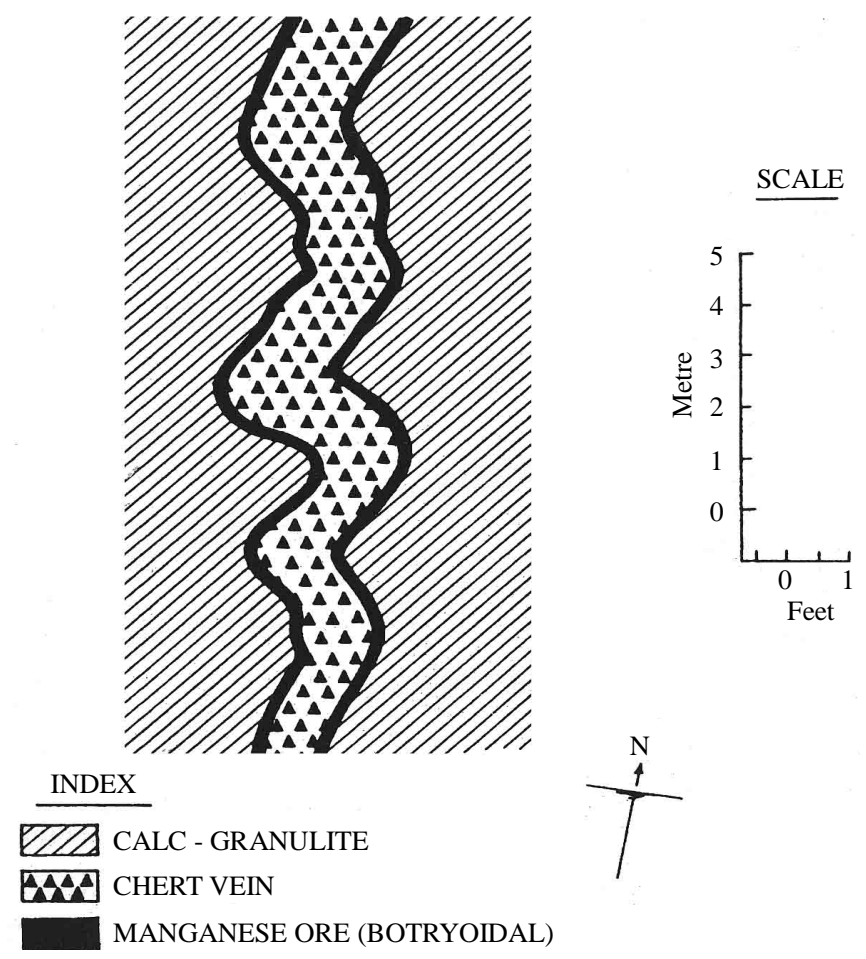

Figure 12. Sketch of a Chert Vein Bordered by Manganese Ore along the fissure of the Calc-Granulite at Sai Baba Pit, N-Garbham, Vizianagram-Visakhapatnam Manganese Belt (A.P.).

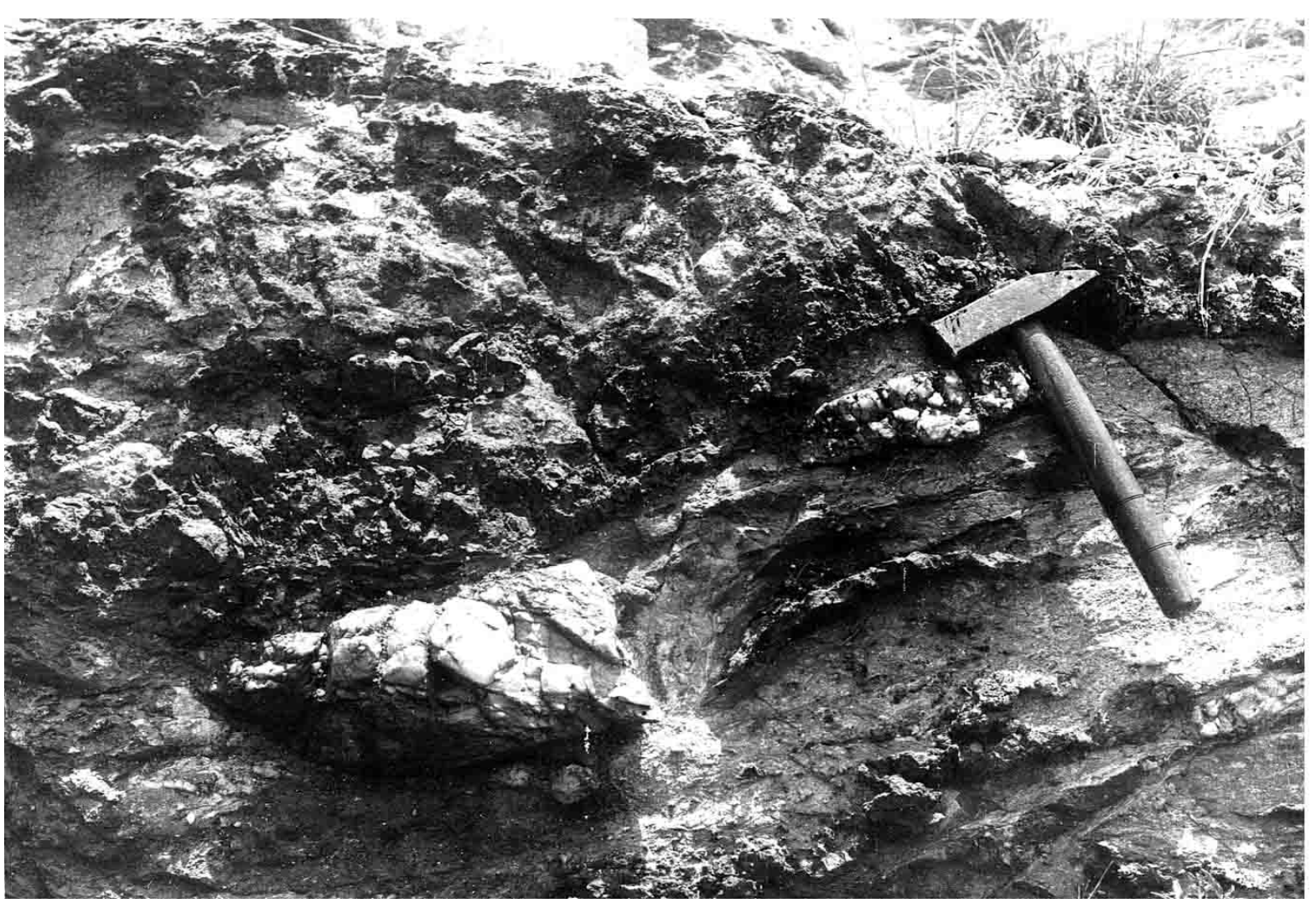

Figure 13. An outcrop of partly weathered khondalite intercalated with manganese ore in "Inclined quarry”, Garividi, Vizianagram-Visakhapatnam Manganese Belt (A.P.). 
Table 2. Chemical composition of the important manganese minerals of Vizianagram-Visakhapatnam Manganese Belt (A.P.) India.

\begin{tabular}{|c|c|c|}
\hline \multirow{3}{*}{ HIGHER OXIDES } & Pyrolusite & $-\mathrm{MnO}_{2}$ \\
\hline & Cryptomelane & $-\mathrm{KMn}_{8} \mathrm{O}_{16}[15]$. \\
\hline & Psilomelane & - $\left(\mathrm{Ba}, \mathrm{H}_{2} \mathrm{O}\right)_{2} \mathrm{Mn}_{5} \mathrm{O}_{10}$ [16] [17]. \\
\hline \multirow{2}{*}{ HYDROXIDES } & Vredenburgite & $-3 \mathrm{Mn}_{3} \mathrm{O}_{4} \cdot 2 \mathrm{Fe}_{2} \mathrm{O}_{3}$ \\
\hline & Manganite & $-\gamma-\mathrm{MnOOH}$ \\
\hline \multirow{4}{*}{ LOWER OXIDES } & Hollandite & $-\mathrm{BaR}_{8} \mathrm{O}_{16}, \mathrm{R}=\mathrm{Mn}^{4+}$ MAINLY, ALSO $\mathrm{Mn}^{2+}$, Fe, Co [18]. \\
\hline & Braunite & $-3 \mathrm{Mn}_{2} \mathrm{O}_{3}, \mathrm{MnSiO}_{3}$ or $\mathrm{Mn}^{2+}\left(\mathrm{Mn}^{4+} \mathrm{Si}^{4+}\right) \mathrm{O}_{3}[19]$ \\
\hline & Bixbyite & - $(\mathrm{Mn}, \mathrm{Fe})_{2} \mathrm{O}_{3}$ \\
\hline & Jacobsite & $-\mathrm{MnFe}_{2} \mathrm{O}_{4}$ \\
\hline \multirow{2}{*}{ SILICATES } & Hausmannite & $-\mathrm{Mn}_{3} \mathrm{O}_{4}$ \\
\hline & Spessartite & $-\mathrm{Mn}_{3} \mathrm{Al}_{2}-\left(\mathrm{SiO}_{4}\right)_{3}$ \\
\hline \multirow{2}{*}{ CARBONATE } & Rhodonite & $-\mathrm{MnO} \cdot \mathrm{SiO}_{2}$ \\
\hline & Rhodochrosite & $-\mathrm{MnCO}_{3}$ \\
\hline
\end{tabular}

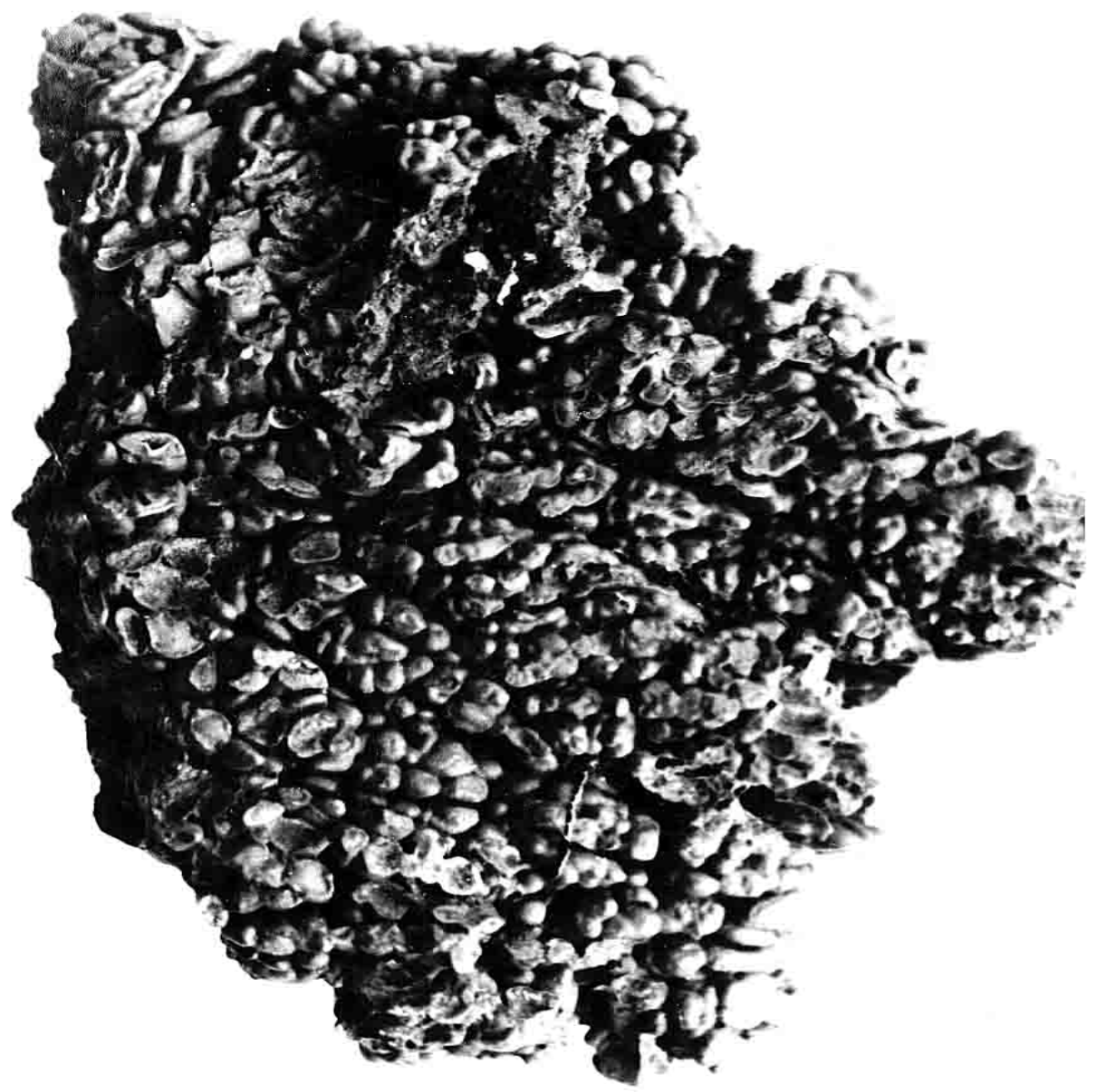

Figure 14. A hand specimen of wad showing cauliflower like form, from Jai Bhawani quarry, Garbham (sample $6 \mathrm{~cm}$ ) Vizianagram-Visakhapatnam Manganese Belt (A.P.). 
reported wad from Mysore (Karnataka), [21] from Keonjhar, Orissa, and [22] from Shivrajpur, Panchmahals district, Gujarat.

Generally wad was found in powdery form, perhaps because it is easily weathered with the greater absorption of moisture.

\subsection{Jacobsite $(\mathrm{Mn}, \mathrm{Fe})_{2} \mathrm{O}$}

Jacobsite is a manganese-iron oxide. Some good specimens of jacobsite were collected from the pockets in Garbham, Sadanandapuram and also in Garividi mines.

Jacobsite ore is generally medium to coarse grained having shining crystals. Colour: dark steel grey hardness: 6; streak: coffee coloured; specific gravity: medium; lusture: metallic, fairly magnetic.

\subsection{Braunite 3 ( $\mathrm{Mn} \mathrm{III,} \mathrm{Fe}$ III $)_{2} \mathrm{O}_{3}, \mathrm{Mn} \mathrm{II} \mathrm{SiO}_{3}$}

The Mn ore occurs at Garividi, Garbham and Chipurupalle mines. It is found in the form of hard and lumpy masses. The braunite vary widely in size, from fine to very coarse grained constituting what [20] termed as "Faceted ores". The associated mineral is garnet.

Colour: dark grey to brownish-black; streak: black, lusture: Subvitreous, fracture: uneven; hardness: 6.0 - 6.5, specific gravity: 4.17 .

\subsection{Laterite}

At Pallapgudi (Garbham) and Avagudem (Chipurupalle) quarries ferruginous laterite occur as thin cappings which sometimes show cavarnous and honey comb like structure. The laterites are hard and appear reddishbrown in colour.

\subsection{Ochre}

Ochre is also found in Duvvam, Garividi (Figure 15) and in the Pallapgudi quarry it occurs in association with mixture of haematitie, limonite and clay. Colour: yellowish brown; hardness: 0.5 - 1.5.

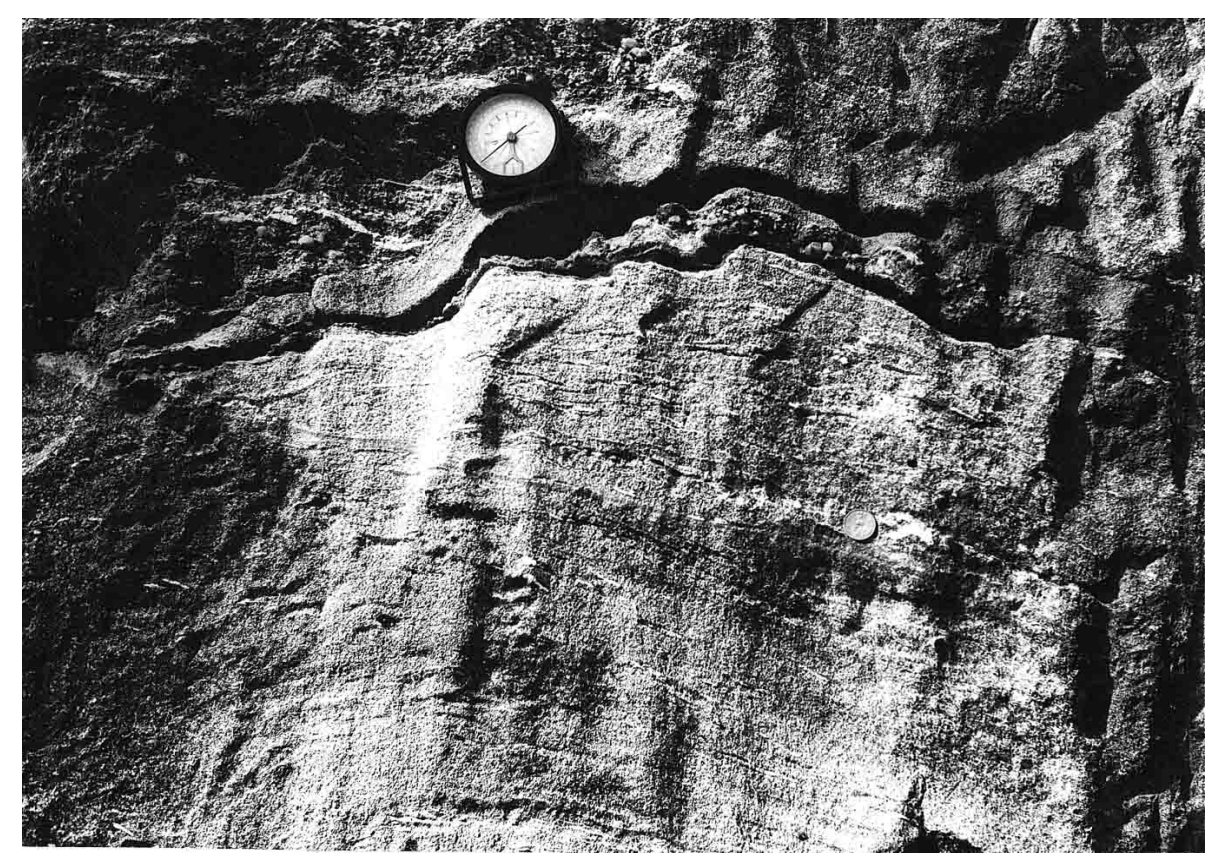

Figure 15. Photograph showing A. Below clinometer one wavy khondalite vein bifurcating into two, vein is highly shattered. B. Lenticles of dull white amorphous quartz and black (oxidised) manganese ore with crystalline quartz vein in Duvvam quarry, Garividi, Vizianagram-Visakhapatnam Manganese Belth (A.P.). 
The manganese ores of Garividi, Koduru, Adilabad and Garbham mine areas of Vizianagram-Visakhapatnam Manganese Belt, consist of primary and secondary minerals particularly those from the oxidation zone. The following minerals are identified by ore microscopy and confirmed by X-ray methods [5] (Table 3).

\section{Conclusions}

Such features as banding, colloform structures, relict silicates and rare pseudomorphs, indicate its secondary nature formed as an alteration product of manganiferous silicates of an early paragenetic sequence.

\section{PARAGENESIS}

\begin{tabular}{|c|c|c|}
\hline$\underline{\text { Minerals }}$ & Primary Sedimentary & $\underline{\text { Secondar }}$ \\
\hline Braunite & & \\
\hline Jacobsite & & \\
\hline Hausmannite & & \\
\hline Bixbyite & & \\
\hline Vredenburgite & & \\
\hline Psilomelane & & \\
\hline Pyrolusite & & \\
\hline Haematite & & \\
\hline Goethite \& Limonite & & \\
\hline Pyrite & & \\
\hline Magnetite & & \\
\hline Molybdenite & & \\
\hline Illmenite & & \\
\hline
\end{tabular}

Table 3. The minerals given in the table are identified by ore microscopy and confirmed by X-ray methods [5].

\begin{tabular}{|c|c|c|c|c|c|}
\hline Name of the Mineral & Garividi & Koduru mine & Adilabad & Andra & Garbham \\
\hline Pyrolusite & + & + & + & + & + \\
\hline Psilomelane & + & + & + & + & + \\
\hline Vredenburgite & + & + & & & + \\
\hline Braunite & + & & + & & + \\
\hline Bixbyite & + & & & & \\
\hline Lithiophorite & + & & & & \\
\hline Franklinite & & + & & & \\
\hline Rhodonite & + & + & & + & \\
\hline Mn-garnet & + & + & & + & \\
\hline Coulsonite & & + & & & \\
\hline Hausmannite & + & + & + & & + \\
\hline Jacobsite & + & + & & + & + \\
\hline + Present & & & & & \\
\hline
\end{tabular}


Pyrite, molybdenite, magnetite and some illmenite are found as interstitial minerals, in cracks and cleavages of silicates forming the latest paragenetic minerals.

The mineral composition and the texture of the manganese ores of Vizianagram-Visakhapatnam Manganese Belt as revealed in this study strongly indicate high-grade metamorphism [23] [24]. According to [25] such mineral association belongs to Mesozone. Further, the ore body occurs in a terrain that is highly metamorphic (granulite facies) and the ore body in its mineral content is analogous to high temperature metamorphic manganiferous deposits of Postmosburg described in detail by [26]. Both the deposits are situated in highly metammorphic Archaean crystallines and contain similar manganese oxides and silicates. The manganese ores of these districts in composition and mode of occurrence are closely related to Gondite type (Madhya Pradesh, India) of a definite metamorphic origin [27]. The ores in question and also the manganese ores of Gondite type (M.P.) contain braunite, jacobsite, bixbyite, spessartite and rhodonite with their own peculiarities. The differences are only in variation in composition leading to the grade of the deposits. Therefore the author concludes that their origin was original sedimentation and metamorphism. The oolites, manganiferous sandstones, the mineral composition, association and mode of occurrence confirm them as primary manganese sediments later metamorphosed.

It may thus be suggested that the Mn-ores are not suitable for ferro-alloy production due to low MN and abnormally high content of the phosphorus [28] and some silicate minerals which have brought down the concentration of manganese in the ore [29].

\section{Acknowledgements}

The authors are grateful to Prof. M. Rahimullah, Chaiman Department of Geology and Dean Faculty of Science, A.M.U., Aligarh. And finally to Director, N.I.O. Dona Paula, Goa, for providing research facilities.

\section{References}

[1] Krishna Rao, J.S.R. (1963) Microscopic Examination of Manganese Ores of Srikakulam and Visakhapatnam Districts, A.P., India. Economic Geology, 58, 434-440. http://dx.doi.org/10.2113/gsecongeo.58.3.434

[2] Rao, G.V. (1969) The Geology and Manganese Ore Deposits of Parts of Vizakhapatnam (Visakhampatnam) Manganese Belt, Srikakulam District, A.P., India. Bulletin Geological Survey of India, A, 35, 129.

[3] Siddiquie F.N. and Shaif Md. (2015). Geochemistry of Major Oxides in Host Rocks in Vizianagarm Manganese Ores Belt (A.P.), India. International Journal of Geosciences, 6, 350-372. http://dx.doi.org/10.4236/ijg.2015.64028

[4] Krishna Rao, J.S.R. (1964) Association of Manganese Ores and the Khondalites in Eastern Ghat, India. Proceedings of 22nd International Geological Congress, 5, 229-238.

[5] Krishna Rao, J.S.R. (1975) Some Problems on the Manganese Ore Deposits of A.P., India. Acta Mineralogica Petrographica, 22, 133-141.

[6] Rao, S.V.G.K., Sarma, K., Jagannadhan, and Bhattacharya, S. (1981). Potential and characteristics of low grade manganese ores in north coastal, A.P., India. In: Proceeding of International Symposium on Beneficiation and Agglomeration, Bhubaneswar, India, January 1991, 2.10a.1-2.10a.6.

[7] Sharma, N.L., Ali, Imam. and Perraju, P. (1974) Geology of Parts of Srikakulam, Chipurupalli and Palakonda Taluks, Srikakulam District, A.P., India. Unpublished Report, Geological Survey of India, Calcutta.

[8] Siddiquie, F.N. (1986) Geology and Geochemistry of Manganese Ore Deposits of Srikakulam District (Andhra Pradesh), India. Unpublished Ph.D. thesis, Geology Department, Aligarh Muslim University, Aligarh, 253 p.

[9] Siddiquie, F.N. (2000) On the Occurrence of Lepocinclis from Khondalites of Srikakulam District (A.P.). Bull. of the Indian Geologist's Association, Chandigarh, 33, 63-68.

[10] The Indian Express (2002) Geologists Discovers New Alga. Science Talk, March 21st, p. 7.

[11] Siddiquie, F.N. (2003) Some Modification in the Stratigraphy of Manganese Bearing Formations, Srikakulam District (A.P.), India. Journal of Science and Technology, 11, 137-154.

[12] Siddiquie, F.N. (2004) Metallogenesis of Manganese Ores of Srikakulam-Visakhapatnam Belt. Icon Publication Pvt. Ltd., New Delhi, 194 p.

[13] Straczek, J.A. and Krishanswamy, S. (1956) Manganese Ore Deposits of the Vizagapatnam (Visakhapatnam) District, A.P., India. Proceedings of the 20th International Geological Congress, Mexico, D. F., Symposium del Manganeso, 4, 141-157.

[14] Hewett, D.F. and Fleischer, M. (1960) Deposits of Manganese Oxides. Economic Geology, 55, 1-55. 
http://dx.doi.org/10.2113/gsecongeo.55.1.1

[15] Richmond, W.E. and Fleischer, M. (1942) Cryptomelane, a New Name for the Commonest of the "Psilomelane" Minerals. American Mineral, 27, 608.

[16] Wadsley, A.D. (1968) Mineralogy of the Different Genetic Types of Manganese Deposits. Economic Geology, 63, 760-786.

[17] Wadsley, A.D. (1953) The Crystal Structure of Psilomelane, $\left(\mathrm{Ba}, \mathrm{H}_{2} \mathrm{O}\right)_{2} \mathrm{Mn}_{5} \mathrm{O}_{10}$. Acta Crystallographica, 6, $433-438$. http://dx.doi.org/10.1107/S0365110X53001277

[18] Fleishcer, M. and Richmond, W.E. (1943) The Manganese Oxide Minerals. Economic Geology, 38, 269-286. http://dx.doi.org/10.2113/gsecongeo.38.4.269

[19] Muan, A. (1959) Stability Relations among Some Manganese Minerals. American Mineralogist, 44, $946-960$.

[20] Fermor, L.L. (1909) Manganese Ore Deposits of India. Memoir of Geological Survey of India, 37, 272.

[21] Sen, B. (1951) Manganese Ores of Keonjhar. Transactions of the Mining, Geological and Metallurgical Institute of India, 47, 85-113.

[22] Rasul, S.H. (1964) A Note on the Occurrence of Manganese Tabloids and Boodinages in the Aravalli Phyllites of Bamankua and Shivrajpur, Gujarat. Current Science, 33, 617.

[23] Siddiquie, F.N. and Raza, M. (2008) Geochemical Environment \& Metallogenesis of Manganese Ores of SrikakulamVisakhapatnam Manganese Belt (A.P.). Proceedings of the 24th Convention and National Seminar on Sedimentary Basin of India and Their Economic Resources, Aligarh, 4-6 March 2008., 86-87.

[24] Siddiquie, F.N. and Bhat, S.H. (2010) Rainwater Harvesting in Abandoned Manganese Mines of Vizianagram-A Geoenvironmental and Geomedical Concern. Proceedings of the Regional Workshop on Water Conservation and Rainwater Harvesting Techniques to Augment the Ground Water and Its Impact on Environment, Aligarh, 5 June 2010, 6.

[25] Harker, A. (1932) Textbook on Metamorphism. Methuen \& Co. Ltd., London, 181 p.

[26] Schneiderhöhn, H. (1932) Minerlbestand und Gefuge der Manganerze von Postmasburg, Sudwestafrika. Neues Jahrbuch, 64, 701-726.

[27] Siddiquie, F.N., Ali, S.A., Bhat, S.H. and Burhamuddin, K. (2015) Genetic Association of Cu, Ni and Cr with the Manganese Ores of Vizianagram District, A.P., India. Journal of Applied Geochemistry, 7, 66-77.

[28] Siddiquie, F.N. (2001) Source of Unusually High $\mathrm{P}_{2} \mathrm{O}_{5}$ in Manganese Ores of Srikakulam District (A.P.), India. Journal of Applied Geochemistry, 3, 78-84.

[29] Siddiquie, F.N. and Raza, M. (1990) Major and Trace Elements Variability in Manganese Ores of Srikakulam District (A.P.). Indian Geologist’s Association, Chandigarh, 99-109. 